\section{Belgian Pasteur institute in "catastrophic" financial crisis}

Brussels

THE Institut Pasteur of Brabant (IPB) is fighting for its survival because its only patron, the provincial government of Brabant, has run into a financial crisis described as "catastrophic". But a petition carrying 5,000 signatures, including 100 of scientists from abroad, has so far failed to persuade the Belgian state government to shoulder Brabant's responsibilities.

Although IPB carries the name of Pasteur, it is independent of the French Institut Pasteur at Paris and Lille. It was set up in 1900 by the Nobel prizewinner Jules Bordet, who took Pasteur's name with the permission of his widow, then still alive, and was given financial support from the provincial government of Brabant in 1903.

The institute's charter covers rabies prevention, the production of sera and vaccines, the diagnosis of infectious diseases and related research. The present staff numbers just over 125 , of whom 15 are professional scientists, but there has been no recruitment for the past ten years and the policy of not replacing members of the staff when they leave or retire is to continue.

Problems have mounted at the institute since 1967 , when work began on buildings to replace the institute's antiquated laboratories to meet the then new stringency of the pharmaceutical industry. But facilities to replace the production laboratories are still not complete, a vital World Health Organisation (WHO) licence was lost and vaccine production has now ceased.

Now, the provincial government says that building work will be abandoned and the production department closed, ostensibly because it is "no longer profitable". Although profits from vaccine and reagent sales, if any, are paid over to the government of Brabant, the institute says that it has never been stipulated that production should make money, but that it will not be possible for a reapplication for the WHO licence to succeed if the new building is not completed.

Meanwhile, the rump of the staff is under further pressure. The overall budget has been reduced by a third in the past two years, while this year's equipment budget (at BFr 2 million) is an eighth of what it was four years ago.

While accepting that IPB's vaccine production is probably too small to be economic, the institute believes that its hope that the Belgian government would allow it to remain intact by replacing Brabant's financial support has been disappointed by the national policy of regionalization aimed at defusing Belgium's long-standing linguistic troubles.

Deputy-director Professor Jean Content, whose research on interferon has won him international respect and which is now supported from national science foundation grants, says that the ending of vaccine production signals the "beginning of the end" for the institute, but that the protest over several months may have ensured that there "will be no sudden changes, but rather a slow death". He believes it ironical that Belgium should be passing up such an opportunity when Brussels sees itself becoming the capital of Europe in 1992.

\title{
Natural History Museum to build DNA database in London
}

\section{London}

A BADLY needed injection of confidence among researchers at the British Museum (Natural History) in London could be on the way following the appointment last month of zoologist Neil Chalmers as director. He has ambitious plans for the museum's DNA sequencing laboratory, due to start operating in mid-1989. It will be used to extract genetic information from the museum's collections of zoological and botanical specimens to build up a large DNA database for taxonomic and phylogenetic purposes. The keeper of zoology, John Peake, has high hopes for the $\$ 200,000$ facility, which will have a staff of three. It will complement biomedical work under way at two other museum laboratories to provide a "cutting edge" in taxonomic research, he says.

Chalmers answers criticisms that the DNA facility is being promoted (and funded) at the expense of more traditional lines of research by pointing out the usefulness of on-site molecular biology expertise in drawing the attention of the museum to a wider circle of biologists than it does at present. Following a review of policy at the museum, in-house researchers will be encouraged to collaborate with colleagues in other institutions, if only as an exercise to break down barriers between museum and university research. Work on extracting DNA from specimens preserved in alcohol is being done in collaboration with the Department of Genetics at the Univer- sity of Nottingham and is an integral part of the DNA project.

And with the approach of a European free market in 1992, Chalmers has already been discussing the coordination of work in natural history museums throughout the EEC with his opposite number in Paris. Contacts with museums in other EEC

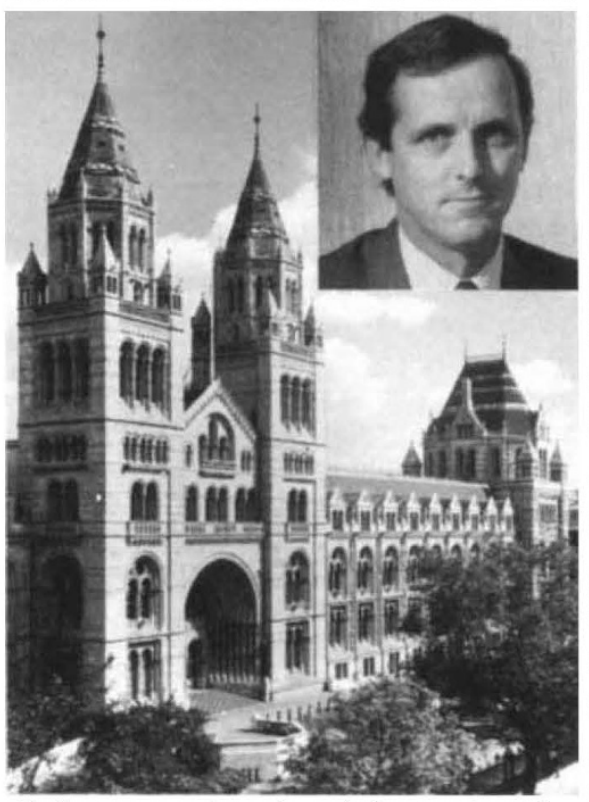

Chalmers - putting science before sentiment?

countries such as the Federal Republic of Germany are in prospect. The most visible fruits of collaboration are likely to be temporary exhibitions. An exhibition on human palaeontology in Europe, scheduled for 1992, will be mounted jointly with a museum in Europe before it goes on tour around the EEC. Chalmers appreciates the publicity value of temporary exhibitions such as the hugely popular display of Chinese dinosaurs (to end next month), a view endorsed by the keeper of palaeontology, Robin Cocks.

But Chalmers will need to win the confidence of his research staff, demoralized by years of cuts. Although there have been no redundancies, jobs left vacant through retirements are rarely filled as resources are redistributed to new ventures, like the DNA laboratory. And worries about the long-term future of many specimens has created a sense of unease. The museum's main site in South Kensington is too small to house Europe's largest collection of natural history specimens, many of which are now stored in warehouses at Ruislip in West London. But the lease is due to expire in 1993, and no alternative site has yet been found, although the Museum is actively looking. The takeover in 1985 of the Geological Museum next door at South Kensington has freed some space, the British Geological Survey having moved to new premises at Keyworth, Nottinghamshire. Chalmers acknowledges the seriousness of the storage problem; researchers fear that valuable specimens damaged in the 8-year job of moving them to the warehouse may be damaged further when the time comes to move them again.
Henry Gee 